\title{
Diversity and Abundance of Ant (Formicidae) Functional Groups in Range of Land Use Systems in Jambi, Sumatra
}

\author{
Keanekaragaman dan Kelimpahan Kelompok Fungsional Semut (Formicidae) pada \\ Berbagai Sistem Penggunaan Lahan di Jambi, Sumatra
}

\author{
F.X. Susilo ${ }^{1 *}$, M. Hazairin ${ }^{1}$, and Suryo Hardiwinoto ${ }^{2}$ \\ ${ }^{1}$ Faculty of Agriculture, Universitas Lampung, Jl. Sumantri Brojonegoro No. 1, Bandar Lampung 35145 \\ ${ }^{2}$ Faculty of Forestry, Universitas Gadjah Mada, Jl. Agro - Bulaksumur, Yogyakarta 55281 \\ E-mail: fxsusilo2000@yahoo.com *Penulis untuk korespondensi
}

\begin{abstract}
Abstrak
Kerusakan hutan tropika basah dapat menimbulkan dampak lingkungan berupa penurunan keanekaragaman hayati dan terganggunya fungsi serta stabilitas ekosistem. Tujuan dari penelitian ini adalah untuk mendapatkan bukti apakah perubahan hutan tropika basah menjadi bentuk penggunaan lahan lain berakibat pada penurunan keragaman dan kelimpahan semut, dan untuk menunjukkan apakah semut dapat dijadikan sebagai bio-indikator perubahan sistem penggunaan lahan (SPL). Penelitian ini dilakukan di Jambi Sumatra pada akhir musim penghujan (Mei-Juni) 2004 pada berbagai taraf intensifikasi SPL. Inventarisasi dan koleksi semut dilakukan dengan menggunakan metode "Winkler" pada enam SPL, yaitu: hutan primer, hutan sekunder, perkebunan karet, perkebunan kelapa sawit, ladang ketela pohon, dan padang alang-alang. Hasil penelitian menunjukkan bahwa ditemukan 50 genus semut pada 6 SPL tersebut. SPL tidak berpengaruh secara nyata terhadap keragaman dan kelimpahan seluruh semut tetapi berpengaruh secara nyata terhadap kelompok semut pesaba dan semut predator. Keragaman jenis dan kelimpahan yang tinggi dari semut predator ditemukan pada SPL hutan primer dan hutan sekunder. Keragaman jenis dan kelimpahan menjadi rendah apabila SPL hutan diubah menjadi SPL ladang ketela pohon. Kelimpahan semut pesaba tertinggi diketemukan pada SPL perkebunan kelapa sawit. Data yang diperoleh menunjukkan bahwa semut dapat digunakan sebagai bio-indikator dalam perubahan SPL di kawasan Jambi, Sumatra.
\end{abstract}

Kata kunci: Sistem penggunaan lahan, semut, keragaman jenis, kelimpahan

\begin{abstract}
The objective of this study was to determine the effect of deforestation in the humid tropics on the diversity and abundance of ants and to show whether ants can be used as a bioindicator for land use changes in the area. Inventory of ants had been conducted during the end of rainy season of 2004 (May-June) in Jambi, Sumatra. Ants were collected using winkler method from 30 sample points across six land use systems (LUS) of increasing intensity, i.e. primary forest, secondary forest, rubber plantation, oilpalm plantation, cassava garden and Imperata grassland. Results showed that, overall we found 50 genera of ants. LUS did not affect the overall ant diversity and abundance but affected the forager ants and predatory ants. The high diversity of predatory ants was found in the primary and secondary forest while their low diversity and abundance were evidentin in the cassava garden. The abundance of forager ants was highest in the oilpalm plantation. Information gathered so far showed that ants can be used as a bioindicator for land use change in Jambi area, Sumatra.
\end{abstract}

Key words: Land use systems, ant, diversity, abundance

Diterima: 13 April 2009, disetujui: 30 November 2009 


\section{Introduction}

Ecosystem comprises of living organisms that form biological diversity (biodiversity). Although not so obvious, the community of soil organisms is very diverse (Giller et al., 1997). Soil faunal communities show a variety of reactions to changes induced by human intervention, including forest conversion. Their abundance and diversity are indicators of the quality of the ecosystem in which they live (Lavelle et al., 1994). Over recent decades natural forests in the tropics have been converted to agricultural and silvicultural systems (Noble and Dirzo, 1997; Tilman et al., 2001). For instance, most areas of Jambi Province in the central part of Sumatra, in 1932 were covered by natural rain forest vegetation, but since 1994 the natural forest has been changed and converted into other land-uses (Van Nordwijk et al., 1995). Changes of tropical rain forest to other land-uses might exert impacts on forest fragmentation and degradation, biodiversity loss and affect the function and stability of the ecosystems.

The loss of below-ground biodiversity has often been associated with forest conversion but adequate evidence needs to be gathered across time and space in order to show the truth of the notion (Giller et al., 1997). Fragoso et al., (1997) reported that land conversion from forest to agroecosystems caused the loss of some species and ecological function of earthworms, which in turn led to the decline of agricultural productivity. However, recently Dewi et al., (2006) reported just the opposite. The conversion from forest to agricultural land in West Lampung increased the species diversity of earthworms due to the invasion of small-bodied exotic species. This could be associated with the decrease in soil porosity (Hairiah et al., 2004). Meanwhile, Jones et al., (2003), Susilo and Aini (2005) reported that more intensive land use systems (LUS) caused the decrease in species diversity and abundance of some feeding groups of termites in Jambi and West Lampung, respectively. With the exception of Susilo and Hazairin (2006), not enough report from Sumatra exists on the effect of forest conversion on ants. This study should contribute to fill the gap.
Ants can be used as the indicator of biodiversity (loss) (Alonso, 2000) as related to land use changes. Some ant species are indeed sensitive to habitat changes (Kaspari and Majer, 2000). Ants distribute widely across the globe and the tropical forests harbor their highest diversity (Jeanne, 1979). In addition, their abundance is high and their functional group also varies (Alonso and Agosti, 2000; Majer, 1983). Some ants are opportunistic foragers (with various feeding habits), while some others feed on more specific prey items, i.e. playing role as consistent predators (Kaspari, 2000). The effect of forest conversion on ants can thus be assessed by comparing ant diversity and abundance in forest with those in other LUS in the vicinity of the forest. This study was aimed at (1) showing evidence whether the forest conversion to various LUS cause ant diversity loss and (2) showing how ants can be used as a bioindicator for land use changes. The case was tested in Jambi benchmark area.

\section{Materials and Methods}

Ant field sampling was done during the end of rainy season, i.e. in the period of MayJune of 2004, across six land use systems (LUS) which were distributed over ca. $6 \mathrm{~km}^{2}$ areas in Jambi, Sumatra stretching from Rantau Pandan, to Muara Kuamang, to Kuamang Kuning area. A stratified-grid procedure (Figure 1) was used to select the sample points in each LUS in the area, i.e. the primary forest (labelled as FLI), secondary forest (FI), rubber plantation (TBI-1), oilpalm plantation (TBI-2), cassava garden (CBLI), and Imperata grassland (Shrb) The first step of the procedure was to prepare a map (generated from a QUICKBIRD satellite imagery) that covers the whole sampling area and its vicinity. The next step was to delineate LUS. Then, grids of $200 \mathrm{~m} \times 200 \mathrm{~m}$ points were set across all LUS in the map, resulting in 312 grid points. Each grid point was then groundchecked to see its eligibility as a sample point based on two criteria, i.e. the ease of access and minimum patch size. A land patch of $20 \mathrm{~m}$ x 20 $m$ in size having a common LUS was determined to be the minimum patch size. From this step 54 eligible sample points were gained. The final 
step of the sample point selection was to randomly take five out of all eligible points per LUS to be the sample points. That way, a total of 30 sample points were determined and these were distributed across the six LUS, i.e. FLI and FI in Muara Kuamang, TBI-1, TBI-2, Shrb, and CBLI in Kuamang Kuning area.

Winkler method (Agosti et al., 2000; Chung and Jones, 2003) was used to collect ants from litter in the sample points. In each sample point fine litter was taken from three Winkler quadrates of $1 \mathrm{~m} \times 1 \mathrm{~m}$ along a transect of $12 \mathrm{~m}$ from the center of sample point. Distance between quadrates in the transect was $6 \mathrm{~m}$. The thickness of the litter was measured using an ordinary ruler up to the nearest centimeters. The gross litter from the three quadrates was then removed, sieved, weighed, and incubated (Susilo and Karyanto, 2005). The sieving was done by two persons for five minutes per quadrate using a Winkler sieve (Jones, 2003). The litter materials passing the sieve, i.e. fine litter (sized $<1 \mathrm{~cm}^{2}$ ) was collected in situ into the Winkler collecting bag for further handling in the incubation room. The fine litter was weighed, placed in the Winkler sieves which were then suspended inside the Winkler bag for incubation for 72 hours under room temperature. During the incubation period the litter dried out, causing ants to leave it and drop off into the collecting bottle containing $70 \%$ alcohol at the base of the Winkler bag. Ant specimens were then preserved in the vials containing $75 \%$ alcohol for identification.

Specimen identification was based on external morphology of the worker ants. Morphological characters used included petiol (number of segments), antenna (number of overall segments, number of clubbed segments, length of the scape), mesosoma (ornament of mesosoma, ornament of propodeum laterally), eye (size and form, location frontally), and gaster (size and color of tergum). Identification was pursued up to generic level under the zoom binocular stereo microscope using Bolton (1994) and Hashimoto (2003) as references. The resulting genus names were then re-checked and compared with color photographs of Sumatra Ants (Alpert and Susilo, 2005) and a reference collection of South East Asian ants (gift from Prof. S. Yamane, Kagoshima University, Japan).

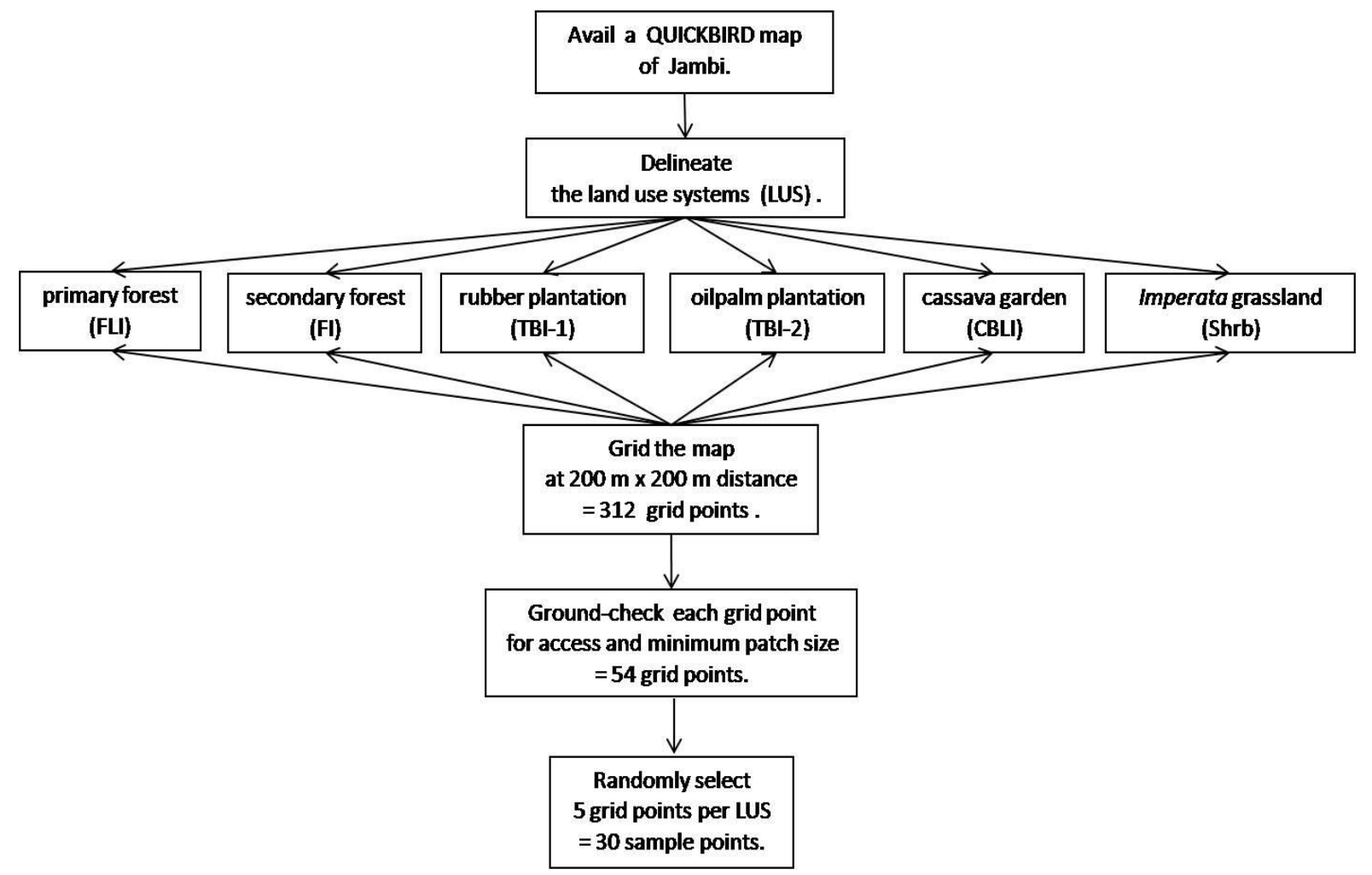

Figure 1. Stratified-grid procedure to select the sample points. 
Tallies of the caught ants were expressed as diversity and abundance. Diversity data was tabulated in number of genera while abundance was expressed in number of catches and percentage of total catches (relative abundance). Diversity or abundance data were also arranged by taxonomic and functional groups. Functional grouping of ants was determined based on Hashimoto (2003) and Brown Jr. (2000). Diversity and abundance data were averaged and compared over LUS using ANOVA and LSD test at 0.05 level of significance. The litter thickness was correlated with the number of ants. The number of predatory ants was also correlated with the number of their prospective prey: termites. The coefficients of correlation were tested using t-test at 0.01 or 0.05 level (Snedecor and Cochran, 1980).

\section{Results and Discussion}

Litter sampling from six LUS in Jambi area resulted in a total of 50 ant genera of seven subfamilies and two major functional groups (Table 1, Figure 2). Myrmicinae (Myr) was the most diverse (with 20 genera) and the most abundant subfamily (75\% of total catches) while the least abundantsubfamilies $(1 \%$ or less of total cathes) were Aenictinae (Aen), Cerapachyinae (Cer), and Pseudomyrmecinae (Pse) which were respectively represented by single genus: Aenictus, Cerapachys, and Tetraponera. Dolichoderinae (Dol) was not as abundant (2\% of total catches) but amply diverse (with five genera). The rest of the subfamilies, i.e. Formicinae (For) and Ponerinae (Pon) contributed to modest diversity ( 8 - 14 genera) and abundance (10 - 11\% of total catches).

The main functional groups of 44 collected ants genera could be identified, i.e. foragers and predators, while those of the others (6 genera) were not identifiable at the moment including that of Loweriella (Dolichoderinae), Calyptomyrmex, Lasiomyrma, Lordomyrma, Paratopula (Myrmicinae), and Rhytidoponera (Ponerinae). One myrmicine genus is seed harvester (Acanthomyrmex) while another is scavenger (Monomorium). Most dolichoderine ants are foragers while most ponerines are predators. Subfamilies found with single genus were identified as predators (Aenictinae, Cerapachyinae, and Pseudomyrmicinae). The largest subfamily (Myrmicinae) consists of predatory ants and forager ants. Some forager ants (Dolichoderus, Philidris, and Oecophylla) sometimes also live in close association (mutualistic symbiosis) with and tend Hemiptera. No hemipteran tenders were found among predatory ants.

LUS did not affect the overall diversity and abundance of ants but affected the forager ants (abundance) and predatory ants (diversity and abundance) (Table 2). The high diversity of predatory ants was found in the primary and secondary forest while the low diversity was in the cassava garden (Figure 3). The cassava garden was also harbored by less abundant predatory ants (Figure 4). However, the abundance of forager ants reached its high level in the oilpalm plantation (Figure 5). It was not so clear as to what components in the LUS caused the ant's dynamics but the diversity of predatory ants seemed to be related with the litter thickness (Table 3), as was also the case with the ants in Sumberjaya, Lampung (Susilo et al., 2005) Afterall, those ants are litter ants so their positive correlation with litter thickness would be self explanatory. But, again, it remains questionable as to why forager ants or overall ants do not correlate with litter thickness (Table 3).

Another explanation perhaps rest with the food source, i.e. food niche hypothesis as suggested in Kaspari (2000). Predatory ants feed on other soil animals encountered in their niches. For instance, Oligomyrmex sp. feed on termites (Brown, Jr., 2000). This study showed that the abundance of Oligomyrmex sp. indeed correlated positively with the abundance of overall termites and of wood-feeding termites (Table 3). It was however quite interesting that no correlation could be detected between the abundance of this termite-feeding ants and that of soil feeding termites (Table 3). Other food sources for ants are plant exudates which may be gained directly from plant nectaries or indirectly via their plantlice symbions (Huxley and Cutler, 1991) which excrete honey dews. This line of argument should be very prospective to explain related ecological questions as: 1) Why are forager ants more abundant in oilpalm plantation than in other LUS (Figure 5)? 2) What are Hemipteran 
symbions associated with some forager ants (Dolichoderus, Philidris, and Oecophylla), their distribution, and abundance? Unfortunately, data from this study were not adequate to provide answers to such questions, therefore further studies are needed.

Table 1. Taxonomic and functional group diversity of litter ants collected from Jambi, Sumatra (May-June 2004).

\begin{tabular}{|c|c|c|c|}
\hline No. & Genus & Subfamily & Functional group* \\
\hline 1 & Aenictus & Aenictinae & Predator \\
\hline 2 & Cerapachys & Cerapachyinae & Predator \\
\hline 3 & Dolichoderus & Dolichoderinae & Forager \& tender \\
\hline 4 & Iridomyrmex & Dolichoderinae & Forager \\
\hline 5 & Loweriella & Dolichoderinae & $?$ \\
\hline 6 & Philidris & Dolichoderinae & Forager \& tender \\
\hline 7 & Tapinoma & Dolichoderinae & Forager \\
\hline 8 & Anoplolepis & Formicinae & Forager \\
\hline 9 & Camponotus & Formicinae & Forager \\
\hline 10 & Myrmoteras & Formicinae & Predator \\
\hline 11 & Oecophylla & Formicinae & Predator \& tender \\
\hline 12 & Paratrechina & Formicinae & Forager \\
\hline 13 & Plagiolepis & Formicinae & Forager \\
\hline 14 & Polyrhachis & Formicinae & Forager \\
\hline 15 & Pseudolasius & Formicinae & Forager \\
\hline 16 & Acanthomyrmex & Myrmicinae & Seed harvester \\
\hline 17 & Calyptomyrmex & Myrmicinae & $?$ \\
\hline 18 & Cardiocondyla & Myrmicinae & Forager \\
\hline 19 & Crematogaster & Myrmicinae & Forager \\
\hline 20 & Lasiomyrma & Myrmicinae & $?$ \\
\hline 21 & Lordomyrma & Myrmicinae & $?$ \\
\hline 22 & Mayriella & Myrmicinae & Forager \\
\hline 23 & Monomorium & Myrmicinae & Scavenger \\
\hline 24 & Myrmecina & Myrmicinae & Predator \\
\hline 25 & Oligomyrmex & Myrmicinae & Predator \\
\hline 26 & Paratopula & Myrmicinae & $?$ \\
\hline 27 & Pheidole & Myrmicinae & Forager \\
\hline 28 & Pheidologeton & Myrmicinae & Forager \\
\hline 29 & Pyramica & Myrmicinae & Predator \\
\hline 30 & Recurvidris & Myrmicinae & Forager \\
\hline 31 & Rhoptromyrmex & Myrmicinae & Predator \\
\hline 32 & Solenopsis & Myrmicinae & Forager \\
\hline 33 & Strumigenys & Myrmicinae & Predator \\
\hline 34 & Tetramorium & Myrmicinae & Forager \\
\hline 35 & Vollenhovia & Myrmicinae & Predator \\
\hline 36 & Anochetus & Ponerinae & Predator \\
\hline 37 & Centromyrmex & Ponerinae & Predator \\
\hline 38 & Diacamma & Ponerinae & Predator \\
\hline 39 & Discothyrea & Ponerinae & Predator \\
\hline 40 & Emeryopone & Ponerinae & Predator \\
\hline 41 & Gnamptogenys & Ponerinae & Predator \\
\hline 42 & Hypoponera & Ponerinae & Predator \\
\hline 43 & Mystrium & Ponerinae & Predator \\
\hline 44 & Odontomachus & Ponerinae & Predator \\
\hline 45 & Odontoponera & Ponerinae & Predator \\
\hline 46 & Pachycondyla & Ponerinae & Predator \\
\hline 47 & Ponera & Ponerinae & Predator \\
\hline 48 & Prionopelta & Ponerinae & Predator \\
\hline 49 & Rhytidoponera & Ponerinae & $?$ \\
\hline 50 & Tetraponera & Pseudomyrmecinae & Predator \\
\hline
\end{tabular}

*) based on Hashimoto (2003) 
Table 2. Results of analysis of variance (F test) of the effect of land use systems (LUS) on various ant variables, Jambi - Sumatra.

\begin{tabular}{cll}
\hline \hline No. & \multicolumn{1}{c}{ Variables } & ${ }^{\mathrm{t}} \mathbf{F}_{\text {statistics }}$ \\
\hline \hline 1. & Total number of ant genera & $1.72^{\text {ns }}$ \\
2. & Number of genera of forager ants & $1.15^{\text {ns }}$ \\
3. & Number of genera of predatory ants & $6.95^{* *}$ \\
4. & Abundance of all ants & $2.39^{\text {ns }}$ \\
5. & Abundance of forager ants & $3.66^{*}$ \\
6. & Abundance of predatory ants & $2.82^{*}$ \\
\hline \hline
\end{tabular}

t)analysis using original data (No. 1-3) and transformed data $\sqrt{x}+0.5$ (No. $4-6$ )

${ }^{\text {ns) }}$ non-significant at $\mathrm{P} \geq 0.05$

$\left.{ }^{*}\right)$ significant at $\mathrm{P}<0.0 \overline{5}$

${ }^{* * *)}$ significant at $\mathrm{P}<0.01$

Table 3. Pearson coefficients of correlation between number of ants and litter thickness or number of termites.

\begin{tabular}{clcc}
\hline \hline No. & \multicolumn{1}{c}{ Correlated variables } & Pearson coefficient (r) & ${ }^{{ }^{\star}}$ t statistics \\
\hline \hline 1. & Predatory ants and litter thickness & 0.555 & $3.529^{* *}$ \\
2 & The ant Oligomyrmex sp. and overall termites & 0.409 & $2.369^{*}$ \\
3. & The ant Oligomyrmex sp. and wood-feeding termites & 0.651 & $4.534^{* *}$ \\
4. & The ant Oligomyrmex sp. and soil-feeding termites & 0.072 & $0.381^{\mathrm{ns}}$ \\
\hline
\end{tabular}

t) analysis using original (untransformed) data

${ }^{\text {ns) }}$ Correlation is not significantly different from zero at 0.05 level

*) Correlation is significantly different from zero at 0.05 level

${ }^{* *}$ Correlation is significantly different from zero at 0.01 level

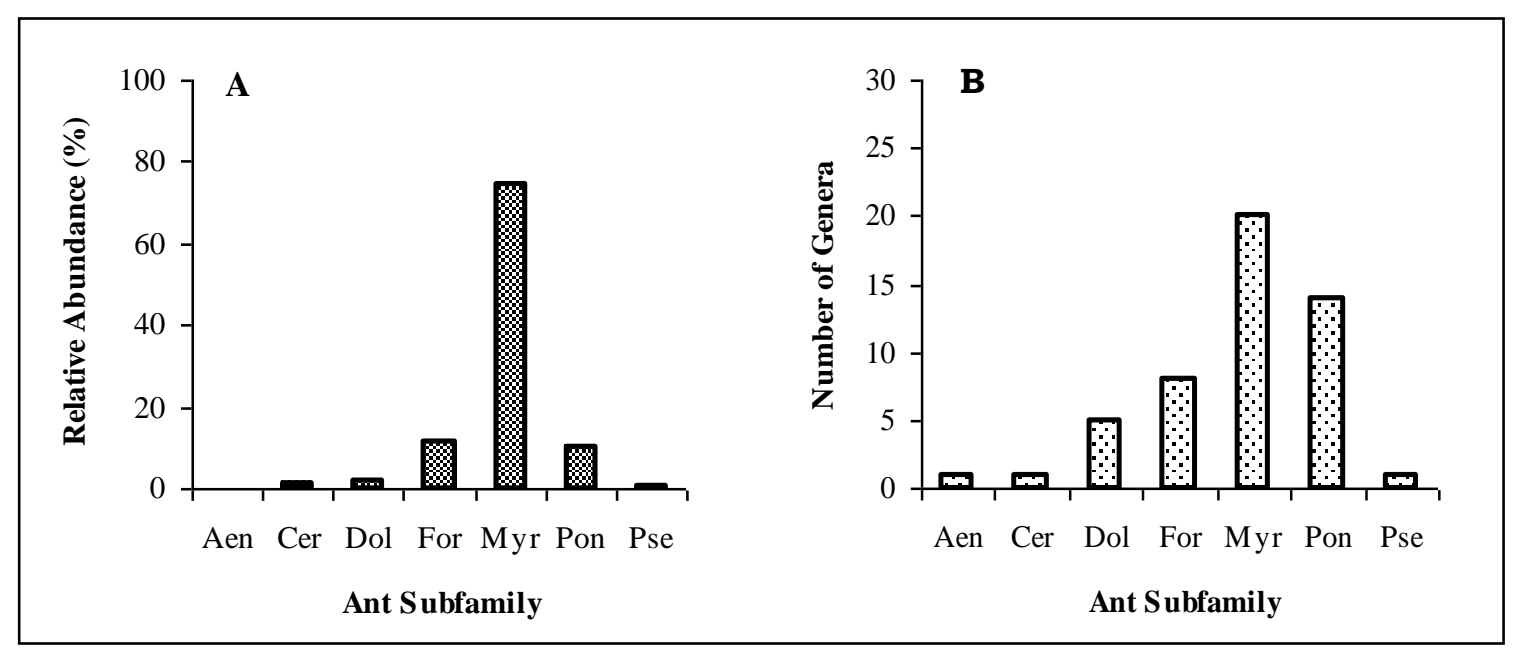

Figure 2. Relative abundance of subfamilies (A) and number of genera (B) of litter ants collected from Jambi, Sumatra (May-June 2004). 


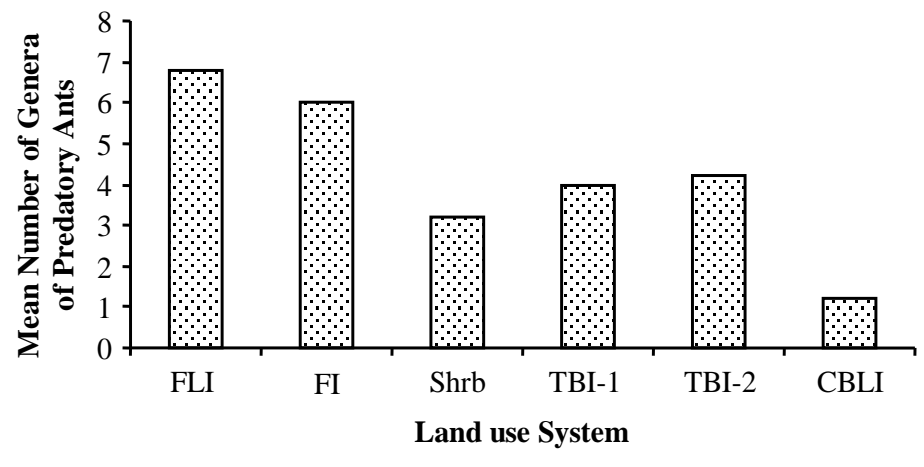

Figure 3. Variations in number of genera of predatory ants across six land use systems in Jambi (FLI = primary forest, FI = secondary forest, Shrb = Imperata grassland, TBI-1 = rubber plantation, TBI-2 = oilpalm plantation, CBLI = cassava garden) .

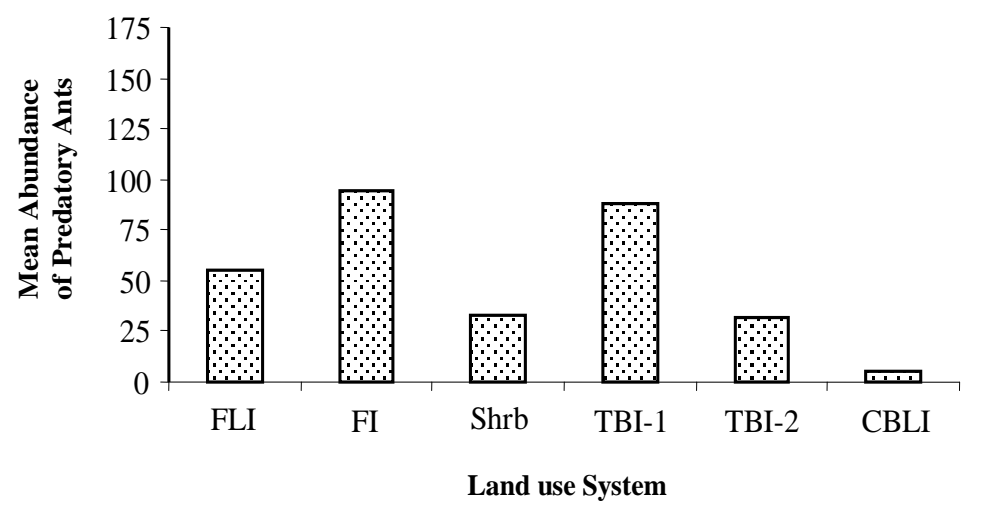

Figure 4. Variations in abundance (N/LUS) of predatory ants across six land use systems in Jambi (FLI = primary forest, FI = secondary forest, Shrb = Imperata grassland, TBI-1 = rubber plantation, TBI-2 = oilpalm plantation, CBLI = cassava garden $)$.

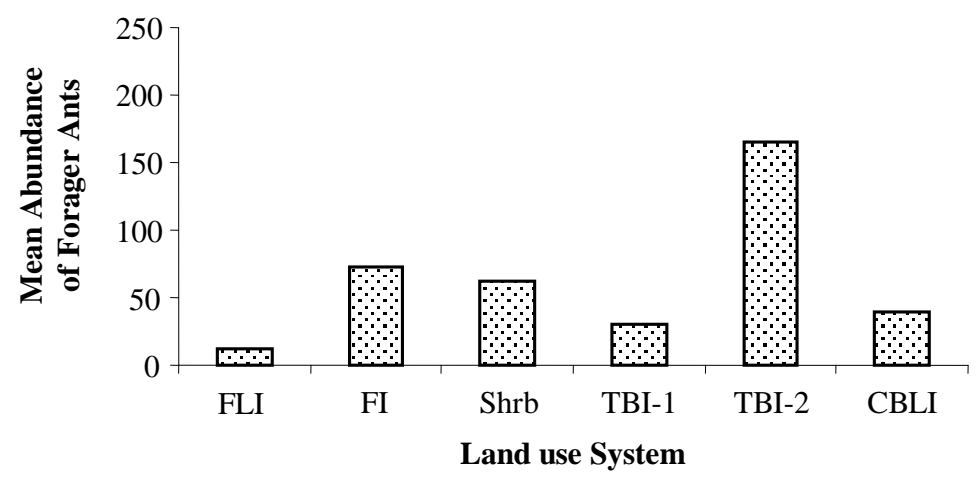

Figure 5. Variations in abundance (N/LUS) of forager ants across six land use systems in Jambi (FLI = primary forest, FI $=$ secondary forest, Shrb = Imperata grassland, TBI-1 = rubber plantation, TBI- $2=$ oilpalm plantation, $\mathrm{CBLI}=$ cassava garden). 


\section{Conclusions}

A total of 50 ant genera of seven subfamilies and two major functional groups were recovered from Jambi area. Myrmicinae was the most diverse and most abundant subfamily while the least abundant subfamilies were Aenictinae, Cerapachyinae, and Pseudomyrmecinae which were respectively represented by their single genera. Dolichoderinae was not as abundant but amply diverse. The rest of the subfamilies, i.e. Formicinae and Ponerinae contributed to modest diversity and abundance. The main functional groups could be identified were forager and predatory ants. Land use systems did not affect the overall diversity and abundance of ants but affected the forager ants and predatory ants. The high diversity of predatory ants was found in the primary and secondary forest while their low diversity and abundance was in the cassava garden. The abundance of forager ants was highest in the oilpalm plantation. The obtained data showed that ants could be used as bioindicator for landuse changes in the area.

\section{Acknowledgements}

This publication presents part of the findings of the international project "Conservation and Sustainable Management of Below-Ground Biodiversity (CSM-BGBD)" implemented in seven tropical countries - Brazil, Mexico, Cote d'Ivoire, Kenya, Uganda, India, and Indonesia. The project is coordinated by Tropical Soil Biology and Fertility Institute of CIAT (TSBF-CIAT) with co-financing from the Global Environment Facility (GEF) and implementation support from the United Nations Environment Programme (UNEP).

The authors are grateful to peer reviewer(s) for valuable suggestions to make this article more readable.

\section{References}

Agosti, D., Majer, J.D., Alonso, L.E. and Schultz, T.R. 2000. Ants: Standard Methods for Measuring and Monitoring Biodiversity. Smithsonian Institution Press, Washington \& London.
Alonso, L.E. 2000. Ants as Indicators of Diversity. In: Agosti, D., Majer, J.D., Alonso, L.E. and Schultz, T.R. (Eds.). Ants Standard Methods for Measuring and Monitoring Biodiversity. Pp. 8088. Smithsonian Institution Press. Washington and London.

Alonso, L.E. and Agosti, D. 2000. Biodiversity Studies, Monitoring, and Ants: an Overview. In: Agosti, D., Majer, J.D., Alonso, L.E. and Schultz, T.R. (Eds.). Ants Standard Methods for Measuring and Monitoring Biodiversity. Pp. 1-8. Smithsonian Institution Press. Washington and London.

Alpert, G. and Susilo, F.X. 2005. Kinds of Ants, Sumatra. In: Alpert, G. (Eds.). Harvard University. http://pick4.pick.uga.edu/mp/20q?act=x_checkli st\&guide=Ants_Sumatra\#Top.

Bolton, B. 1994. Identification Guide to the Ant Genera of the World. Harvard University Press, Cambridge, Massachusetts.

Brown, Jr.W.L. 2000. Diversity of Ants. In: Agosti, D., Majer, J.D., Alonso, L.E. and Schultz, T.R. (Eds.). Ants Standard Methods for Measuring and Monitoring Biodiversity. Pp. 45-79. Smithsonian Institution Press. Washington and London.

Chung, A.Y.C. and Jones, D.T. 2003. Extraction Rates of Soil Arthropods Using the Winkler Bag Sampling Technique. In: Ones, D.T. (Eds.). Tools for the Rapid Assessment of Soil Invertebrate Biodiversity in the ASEAN Region. Pp. 30-40. Handbook to Accompany the Training Course. J Universiti Malaysia Sabah, Kota Kinabalu.

Dewi, W.S., Yanuwiyadi, B., Suprayogo, D. and Hairiah, K. 2006. Can Agroforestry Systems Maintain Earthworm Diversity after Conversion of Forest to Agricultural Land? Agrivita, 28 (3): 198-220.

Fragoso, C., Brown, G., Patron, J.C., Blanchart, E., Lavelle, P., Pashanasi, B., Senapati, B. and Kumar, T. 1997. Agricultural Intensification, Soil Biodiversity and Agroecosystem Function in the Tropics: the Role of Earthworm. Appl. Soil Ecol. 6: 17-35.

Giller, K.E., Beare, M.H., Lavelle, P., Izac, A.M.N. and Swift, M.J. 1997. Agricultural Intensification, Soil Biodiversity and Agroecosystem Function. Appl. Soil Ecol. 6: 3-16.

Hairiah, K., Suprayogo, D., Widianto, Berlian, Suhara, E., Mardiastuning, A., Widodo, R.H., Prayogo, C. and Rahayu, S. 2004. Alih Guna Lahan Hutan Menjadi Lahan Agroforestri Berbasis Kopi: Ketebalan Seresah, Populasi Cacing Tanah dan Makroporositas Tanah. Agrivita, 26 (1): 68-80. 
Hashimoto, Y. 2003. Identification Guide to The Ant Genera of Borneo. In: Hashimoto, Y. and Homathevi, R. (Eds.). Inventory and Collection: Total Protocol for Understanding of Biodiversity. Pp. 89-162. Research and Education Component BBEC Programme, IBTP, Univ. Malaysia Sabah, Kota Kinabalu.

Huxley, C.R. and Cutler, D.F. 1991. Ant-plant Interactions. Oxford University Press, Oxford.

Jeanne, R.L. 1979. A Latitudinal Gradient in Rates of Ant Predation. Ecology, 60: 1211-1224.

Jones, D.T. 2003. Tools for the Rapid Assessment of Soil Invertebrate Biodiversity in the ASEAN Region. Training Course Dates: 13-25 October 2003. Universiti of Malaysia Sabah, Kota Kinabalu.

Jones, D.T., Susilo, F.X., Bignell, D.E., Hardiwinoto, S., Gillison, A.N. and Eggleton, P. 2003. Termite Assemblage Collapse Along a Land-use Intensification Gradient in Lowland Central Sumatra, Indonesia. J. Appl. Ecol. 40: 380-391.

Kaspari, M. 2000. A Primer on Ant Ecology. In: Agosti, D., Majer, J.D., Alonso, L.E. and Schultz, T.R. (Eds.). Ants Standard Methods for Measuring and Monitoring Biodiversity. Pp. 9-24. Smithsonian Institution Press. Washington and London.

Kaspari, M. and Majer, J.D. 2000. Using Ants to Monitor Environmental Change. In: Agosti, D., Majer, J.D., Alonso, L.E. and Schultz, T.R. (Eds.). Ants Standard Methods for Measuring and Monitoring Biodiversity. Pp. 89-98. Smithsonian Institution Press. Washington and London.

Lavelle, P., Dangerfield, M., Fragoso, C., Eschenbrenner, V., Lopez-Hernandez, D., Pashanasi, B. and Brussaard, L. 1994. The Relationship Between Soil Macrofauna and Tropical Soil Fertility. In The Biological Management of Tropical Soil Fertility (Eds. Woomer, P.L. and Swift, M.J.). John Wiley \& Sons.
Majer, J.D. 1983. Ants: Bioindicators of Minesites Rehabilitation, Land use, and Land Conservation. Environ. Mgt. 7 (4): 375-383.

Noble, I.R. and Dirzo, R. 1997. Forests as HumanDominated Ecosystems. Science, 277: 504-509.

Snedecor, G.W. and Cochran, W.G. 1980. Statistical Methods. $7^{\text {th }}$ ed. The Iowa State Univ. Press, Ames.

Susilo, F.X. and Aini, F.K. 2005. Diversity and Density of Termites in a Range of Land use Types in the Rigis Hill Area, Sumberjaya - Lampung. $J$. Sains Tek. 11 (3): 129-136.

Susilo, F.X. and Hazairin, M. 2006. Forest Conversion into Coffee-based Agroforestry Systems in Sumberjaya Reduces Abundance of Predatory Myrmicine Ants. Agrivita, 28 (3): 238-252.

Susilo, F.X. and Karyanto, A. 2005. Methods for Assessment of Below-ground Biodiversity in Indonesia. Universitas Lampung Press, Bandar Lampung.

Susilo, F.X., Murwani, S., Dewi, W.S. and Aini, F.K. 2005. Effect of Land use Intensity on Diversity and Abundance of Soil Insects and Earthworms in Sumberjaya, Lampung. Paper Presented at Seminar Nasional \& Kongres I Masyarakat Taksonomi Fauna Indonesia, 29-30 November 2005 at Universitas Gadjah Mada, Yogyakarta.

Tilman, D., Fergione, J., Wolff, B., D’Antonio, C., Dodson, A., Howarth, R., Schindler, D., Schlesinger, W.H., Simberloff, D. and Swackhamer, D. 2001. Forecasting Agriculturally Driven Global Environmental Change. Science, 292: 281-284.

van Noordwijk, M., Tomich, T.P., Winahyu, R., Murdiyarso, D., Suyanto, Partoharjono, S. and Fagi, M. 1995. Alternatives to Slash-and-Burn in Indonesia. Summary Report Phase 1. ASBIndonesia Report No. 4, Bogor. 